\title{
Problems Facing Small and Medium Size Contractors in Swaziland
}

\author{
Wellington Didibhuku Thwala ${ }^{1}$, Mpendulo Mvubu² \\ ${ }^{1}$ Department of Quantity Surveying and Construction Management, University of Johannesburg, Johannesburg, South Africa; \\ ${ }^{2}$ Department of Construction Management and Quantity Surveying, University of Johannesburg, Johannesburg, South Africa. \\ Email: didibhukut@uj.ac.za
}

Received June 20, 2009; revised August 1, 2009; accepted September 19, 2009.

\begin{abstract}
The paper explores the problems facing Small and Medium Size Contractors in Swaziland. The construction sector in Swaziland is not only a significant source of direct employment but also a sector which contributes, through its wide range of projects and operations. The paper will also look at the current government initiatives that had been put in place to address the challenges and problems in order to ensure that contractors are successful. There is a high failure rate among small and medium size contractors in Swaziland. These contractors fail for a variety of reasons ranging from lack of adequate capacity to handle the uniqueness, complexity and risks in contracting, lack of effective management, lack of business management, poor record keeping and inadequate technical, financial and contract managerial skills. Drawing on research on small and medium size contractors, the paper used both secondary and primary literature. 100 questionnaires were distributed to different role players in the construction sector in Swaziland. The response rate was eighty seven (87) percent. The paper reveals that the most problems facing small and medium size contractors in Swaziland is lack of access to finance and late payment by government. The paper closes with recommendations and key lessons for the future.
\end{abstract}

Keywords: Contractor, Construction, Employment, Small and Medium Size, Public Works

\section{Introduction}

In Swaziland and other countries there seem a general consensus that small enterprises are the mainstay of economic growth and prosperity. Small contractors can be powerful instruments of generating job opportunities; small contractors can perform small projects at different and remote geographical locations that might be unattractive to big firms or too costly using the big firms; low overheads enable small contractors to work at more competitive prices; large number of functional small and medium scale black contractors can help to decentralise the construction industry dominated by established large contractors; the relatively low skills and resources required at this scale can easily lower the entry point for the small and medium size owners to begin to participate in the industry; and a large number of functional Swazi owned contractors can develop a platform for growth and redistribution of wealth in Swaziland. Small and Medium Size contractors in Swaziland are defined as those contractors who do work up to E20 million (Exchange Rate: $\$ 1=\mathrm{E} 8$ ). At a time when the public sector and big business are shedding jobs, small businesses are maintaining real employment growth. The small contractor development programme falls under the Ministry of Public Works and Transport. The main mandate of the ministry is to ensure the provision and maintenance of a sustainable public infrastructure, an efficient and effective seamless transport system and network, regulation for a vibrant construction and transport industry, management of public service accommodation and the provision of meteorological services [1].

\section{Research Objectives}

The main objective of this paper is to outline the problems faced by small and medium size contractors in the Kingdom of Swaziland.

\subsection{Review of South African Literature}

2.1.1 Skill Development in the Construction Industry Historically, the construction industry has largely relied on a core of highly skilled staff (generally white and often expatriate) to supervise a largely semi-skilled and unskilled workforce (generally black). The decline in demand for construction products over the past decades, and associated uncertainty, has seen a reduction in skills 
training since the 1980s, and the closing down of industry training institutions in the 1990s. It has been reported that only about 70 percent of the available training capacity is currently being utilized [2]. Skills enhancement in the construction industry faces a very particular challenge since the construction sector employs the fourth highest number of persons having no formal education after agriculture, households and mining. Industry has expressed a view that skills supplied to the market through the Further Education and Training (FET) system were in many cases not appropriate to their needs, resulting in a skills gap. While industry-based training is seen as better aligned with company-specific requirements, South African Qualification Authority (SAQA) does not accredit some trainers, and some do not issue certificates for training and employment. This tendency limits mobility and career path prospects [2].

The important note was to recognize the improvement of the work skills of all South Africans, which is critical to grow the national economy. The Skills Development Act (SDA) was promulgated to create the structures and framework for the national development strategy. In terms of the SDA employers are obliged to provide formal structured education to their workers, hence in the problem statement one looks at the possibilities of the employed trained people by Group Five being given the opportunity to further their training.

Furthermore, the act encourages partnership in this effect between government, employers, workers, education and training providers, and beneficiary communities. The trained people are the beneficiaries from the community. According to SDA, the needs of employers, the economy and the communities must dictate which skills development should be developed. The part of which skills should be developed lead one to the last objectives in the problem statement to try to identify which skills are often needed in different trades and provinces.

The SDA covers structured, targeted and generic training implying that all training interventions should be planned and managed as projects that is the reason why Group Five has "people at the gate" which is Corporate Social Investment Project. In SDA, employers together with their workers formulate workplace skills plan (WSP) to enable them to realize their employment training targets. All designated employers pay a monthly skills development levy of $1 \%$ of their budgeted payrolls to the National Skills Fund (NFS), via South African Revenue services (SARS). Of this amount, the employer can claim back $70 \%$ in the form of discretionary grant, provided that they submit WSP and Implementation Report (IR) annually and conduct special training projects.

These levies finance the implementation of the National Skills Development Strategy (NSDS). Construction Education and training Authorities (CETA) receives $10 \%$ of the skills levies paid by construction employers for administration costs, NSF receives $20 \%$, and $70 \%$ is available to be claimed back by these contributing employers. However, international trends shows that companies need to spend between $4 \%$ and $7 \%$ in order to be successful in addressing the current shortages and gaps [3]. Furthermore, there appears to be over-reliance of a number of levels in the micro and provincial economy on the SETA's as being responsible bodies for coordinating the identification of scare skills in South Africa.

\subsection{Small Contractors in South Africa}

In South Africa, the contractors enter the market at the lower end and in the general building contracting category, making the sector extremely competitive and unsustainable [4] and the emerging contractor policies intended for black economic empowerment (BEE) are being used as job creation opportunities, which contributes to the over crowding of the emerging market. It is common for black businesses to be based on technical skills which are based on technical skills, which are used to satisfy needs of the community. However, technical competence is no guarantee of business success. Operational (e.g. scheduling and ordering) and business (e.g. planning, financial control and budgeting) skills are vital to the success of any enterprise. Small enterprises contribute positively to the economics of the country and to the survival of large numbers of people.

\subsubsection{Skills Shortage in Small Contractors}

South Africa is characterized by a systematic underinvestment in human capital. This has resulted in a labour force with a skewed distribution of craft skills, career opportunities and work-place experience. While the promulgation of the Skills Development Act of 1997 is commendable, micro enterprises already express concern about the administration costs of recovering levies in the form of grants for training. Furthermore, there are the costs of designing a workplace training programme as an alternative to using external training institutions and the relatively high charges by private training institutions after the closure of the former industrial training boards which had been subsidized through levies from industry [5]. The imbalances of the past with regard to the school curriculum known as "Bantu education" which did not offer much mathematic and science as part of the curriculum hinder the emerging market as these subjects are essential for entry into the engineering and built environment industry. This Bantu system secured the exclusion of black people from participating in the construction industry as they did not have the necessary skills required. According to Matas [6] the Bantu Education Act, Act No. 47 of 1953 established a Black Education Department in the Department of Native Affairs which would compile a curriculum that suited the nature and requirements of black people. The aim was to prevent 
Africans receiving an education that would lead them to aspire to positions they wouldn't be allowed to hold in society. Africans were to receive an education designed to provide them with skills to serve their own people in the homelands or work in labouring jobs under whites. On the other hand the job reservation of 1951 applied to Blacks, Coloureds and Indians. The notion behind job reservation was the best, the most highly skilled jobs, should be reserved for whites. The 1951 Native Building Workers Act provided that no Black might be employed as skilled building workers outside of a Bantu area [6]. The above discussed Acts created a skills shortage among the Africans to compete in the labour market.

\subsection{Financial Constraints}

The high competition among emerging contractors has contributed to increase financial failures of the emerging market, making the market unsustainable. The Construction Industry Development Board [4] states that the large numbers of emerging contractors have moved into higher value public tendering in the $0.5 \mathrm{~m}$ to $2 \mathrm{~m}$ market, which is also becoming overly competitive. Statistics South Africa [7] reports that, from 1995 to 2005, about 5907 construction companies were formally liquidated. According to the Construction Industry Development Board [2] states that much more than $90 \%$ of the emerging black contractors survive the first five years. According to the SA Construction Industry Status Report [2], 1,400 construction companies were liquidated over the past three years. Emerging contractors feel that the banks are reluctant to deal with them unless exorbitant interest rates and through compulsory business management services. Lack of access to finance both during preconstruction which disqualifies emerging contractors from meeting guarantee and performance bond requirements and during construction which leads to cash-flow problems, incomplete work and even liquidation are financial constraints facing emerging contractors. The inadequacy of external finance at the critical growth/transformation stages of micro enterprises deters the enterprises with growth potential from expanding [8].

\subsection{Late Payment by Clients}

Small contractors run into problems due to late payments by the clients. Delays with interim and final payments, as well as onerous contract conditions faced by construction firms, can also impose huge constraints on the industry. Many construction firms have suffered financial ruin and bankruptcy because of delays in payment, which are common with government contracts. The unlucky contractor, failing to repay loans in a timely fashion had his business put into liquidation.

\subsubsection{Difficulties When Running the Businesses}

The following are the lessons that had been learnt in South Africa with regard to the problems facing small contractors in the contractor development programme (Construction Industry Development Board, Department of Public Works, Construction Education and Training Authority [4] are as follows:

- Usually open adverts are placed in the media calling on people to come out and participate; it is very difficult for a selection process to capture those with the proper drive, passion and ability to work as contractors; this brings wrong people in the programs and drives them easily on the way.

- $\quad$ The required academic qualification is usually matric (Grade 12) or less; no prior technical and managerial skills/experience in construction related fields as prerequisites.

- $\quad$ Few matric (Grade 12) holders make rare success; most successful contractors have degree or diploma in construction related field, with 5-10 years technical and managerial work experience.

- Inadequate training done at short period's inbetween projects; unsuitable for the contractor's time and project need; inappropriate trainers.

- $\quad$ Clear-cut grading criteria had been elusive; recently CIDB graded/categorized the contractors using some contested criteria; core tech and management staff not stated, this may still lead to contractors getting projects they do not have capacity for.

- The contractors do not seem to understand the nature of complexity and risk in contracting; do not seem to be adequately informed of how to deal with them properly.

- $\quad$ The contractors lack skill, experience and tools to win profitable contract; they either win a grossly under-priced bid, or lose a grossly over-priced one. Cost, price, control program not provided

- $\quad$ They lack own ready finance and access to affordable loan. Due to lack of collateral, any one that gets credit from banks is subjected to high interest and financial risk management charges that make contracts unprofitable.

- In the ambition to grow big and make big profit, most of them take projects they do not have the necessary skills and financial resources to execute.

- $\quad$ The contractors tend not to employ qualified worker; they consider them expensive, but they fail while doing things all by themselves or with cheap, incompetent workers.

- $\quad$ They lack skills to properly program projects resources in monthly segments for healthy cash flow; they are not allowed front load due to lack of trust; they do not know how to prepare documents for timely payment; delayed payment. 
- They do not seem to understand terms of contract conditions; do not know how to use applicable contract performance procedure to deal with client; they do not get properly trained in this.

- $\quad$ They are usually considered incapable of doing competent work, which imperils their relationship with the client's agent; they do not seem to know how to use applicable contractual instruments regarding instruction, demand for specific performance, and payment; they are not properly taught; where they know these rules they fail to use them due to fear of being 'red listed'.

- In attempt to make huge profit they cut specified quality, do bad work that falls short of the design standards/specification. Rejection of such works usually leads to none payment, conflict and most times failure of the contractors.

- Those that manage to win profitable contracts get only $2 \%$ profit if they are able to successfully complete the project; it seems discouraging.

The studies show that enterprise success is greatly increased by having relatively stable access to markets and access to capital from external sources, and that successful enterprises are characterized by entrepreneurs with a basic level of education, essential technical knowledge and previous industry experience with larger enterprise, and ability to learn new skills, innovate and take risks [9].

\subsubsection{Review of Literature - Swaziland}

The Ministry of Public Works and Transport [1] is a major contributor in the Swaziland construction industry. The Ministry is Government's implementing agency on behalf of all ministries with regard to all government construction capital projects. The role of the Swaziland Government through the Ministry of Public Works and Transport is to educate the small and medium contractors about government's expectations to the tendering process and information required for qualification. Another important aspect of the dissemination of knowledge to contractors is that of information on the standard of workmanship required in government projects. The Ministry of Public Works and Transport is responsible for initiating; the payment process to contractors by preparing the monthly interim certificates. This is very important to contractors in that the speedy execution of payments will ensure that contractors are paid in time and their cash flow is not stretched to the limit.

\subsubsection{The Construction Industry in Swaziland}

The Government of the Kingdom of Swaziland, through its 25-year National Development Strategy (NDS) has identified the construction sector as a priority area to impact on improving the social and economic development of the country. However, to maximize the impact of the sector as part of the NDS, it will be necessary to de- velop a sound national policy framework for the industry to improve its overall effectiveness and efficiency. Fundamental to the policy and in line with the NDS, will be the empowerment of local Swazis within the industry to maximize their participation and consequent impact on the local economy. As far back as 1993, the Government, through the then Ministry of Public Works and Roads took the initiative to organize the Southern Africa Construction Industry Initiative (SACII) on behalf of ten countries of the Southern Africa Development Community (SADC) region. At that time, the overall objectives of the Initiative were to:

- Identify constraints to the development of local construction industries in each participating country within the region;

- Identify specific policy reform to improve the enabling environment for local construction industry growth and development;

- Implement reforms in member countries with Government and donor commitment to local construction industry development.

In general, the main intention of the Initiative was to create jobs, develop local capability and empower local/indigenous companies in the construction industry and is directly in line with the policy framework required by stakeholders in Swaziland. Hence, some of the recommendations and policy options developed as part of the 1993 initiative at national and regional level have been used as a foundation for the framework presented here.

\subsubsection{The Swaziland Construction Industry Policy}

The vision of the government of the Kingdom of Swaziland, as stated in the Swaziland National Construction Industry Policy 2002 [1] advocates for "a construction industry that maximizes "local participation." The construction industry is not only a considerable source of direct employment, but also an industry which contributes to the overall economy of Swaziland, through its extensive assortment of projects and operations. Since the Swazi economy is unable to provide employment for the ever growing population in Swaziland, focus may be turned to the local construction industry. The contribution of the construction industry to the Swazi economy comes in the form of job creation, development of local capability and the empowerment of local indigenous companies in the construction industry.

The Swaziland Construction Industry Policy intended to create an enabling environment to best meet the needs of the stakeholder in the construction industry in Swaziland and commits Government to various roles, functions and activities. In the past, Government's role has been as a regulator and, in some cases, provider of physical infrastructure with no holistic policy framework and strategic plan to drive the industry. Through the policies de- 
veloped, Government intends to refocus its primary role to that of policy and strategy formulation, and regulation of the industry with a reduced direct involvement in the provision of infrastructure and services. The implications are that the capacity and capabilities of the local private sector need to be developed to undertake some of the services previously carried out by Government.

It is also the intention of Government to include other key role players in the co-ordination of the industry and the development of broader national strategies that may otherwise not be achieved successfully. A regulatory role will be retained by Government to ensure safety and quality of service throughout the industry and to monitor progress in achieving the vision and mission of the industry presented here. This will mean, a more focused and skilled national Government that can control, monitor and regulate the relationships between service providers and implementing agencies.

Government also recognizes that the local human resource pool of the construction industry needs to be strengthened to achieve the vision and mission. It is also of concern that there is a significant loss of trained personnel to improved opportunities in other countries. Hence, Government will assume a responsibility for empowerment and capacity enhancement of the local industry through the retention of trained personnel and a general improvement of the resource pool in the industry. However, Government will also seek to involve the private sector in meeting the challenge of growing and retaining the country's human resource base.

\subsubsection{Contractor Accreditation Process in Swaziland}

A registration of accredited construction enterprises in Swaziland constitutes an essential tool for the industry transformation, for monitoring the performance of enabling environment programmes, and for ensuring compliance with the performance of public-sector projects.
All construction enterprises engaged in public sector work, or in receipt of State funding training or support functions, will be required to be registered in a manner that will reflect their capacity and performance. The registration process must address the following: the operation of a preference scheme, or approved public tender list, which would reduce industry and public sector cost associated with an all out open tender process at the same time supporting risk management; performance monitoring to enable the promotion of improved contractors and to ensure compliance where standards are violated; and; the targeting of resources to the emerging contractors which are demonstrating progress and the withdrawal of support from those which have graduated or have failed to progress [1].

Contractor grading in Swaziland is one of the tools that is used to regulate the construction sector. Unlike the Republic of South Africa where the contractor accreditation is done by an independent body, the Construction Industry Development Board (CIDB), each department in the Ministry of Public Works and Transport done its own accreditation. The categories start from category 1 to 6 as illustrated on Table 1 for the roads department. Below the table shows the different categories. The small and medium size contractors in Swaziland fall between categories 2 to 6 . The tender price category is below R500, 000.00 and less than R20m.

In addition to the contractors summarized in the table above, there are twelve (12) specialist contractors; with four (4) specializing in road marking, six (6) specializing in electrical works (streetlight maintenance) and two (2) specializing in premix road maintenance.

As shown in the Table 2 below there are no foreign contractors under main category M1 and sub-category B, $\mathrm{C}$ and D. The table below clearly shows that the Building Contractors are dominated by Swazi people.

Table 1. Civil contractor grading (roads department) in Swaziland

\begin{tabular}{cccl} 
Categories & $\begin{array}{c}\text { Local } \\
\text { contractors }\end{array}$ & $\begin{array}{c}\text { Foreign } \\
\text { contractors }\end{array}$ & \multicolumn{1}{c|}{ Project Category Eligible to tender for } \\
\hline Category 1 & 1 & 2 & $\begin{array}{l}\text { Locally and internationally funded construction projects } \\
\text { above E20 million. }\end{array}$ \\
Category 2 & 1 & 2 & $\begin{array}{l}\text { Local and internationally funded construction projects } \\
\text { above E10 million but below E20million. }\end{array}$ \\
Category 3 & 4 & 0 & $\begin{array}{l}\text { Local and internationally funded construction projects } \\
\text { above E5 million but below E10million. }\end{array}$ \\
Category 4 & 6 & 0 & $\begin{array}{l}\text { Local and internationally funded construction projects } \\
\text { above E1million but below E5million. }\end{array}$ \\
Category 5 & 24 & 0 & $\begin{array}{l}\text { Local and internationally funded construction projects } \\
\text { above E500, 000.00 but below E3million. }\end{array}$ \\
\hline
\end{tabular}

Source: Ministry of public works and roads- Swaziland: 2007. 
Table 2. Contractor grading (buildings department) in Swaziland

\begin{tabular}{cccl} 
Categories & $\begin{array}{c}\text { Local } \\
\text { contractors }\end{array}$ & $\begin{array}{c}\text { Foreign } \\
\text { contractors }\end{array}$ & \multicolumn{1}{c}{ Project Category Eligible to tender for } \\
\hline Category M & 8 & 5 & $\begin{array}{l}\text { Locally and internationally funded construction projects } \\
\text { above E20 million. }\end{array}$ \\
Category M1 & 6 & 0 & $\begin{array}{l}\text { Local and internationally funded construction projects } \\
\text { above E10 million but below E20million. }\end{array}$ \\
Category A & 11 & 2 & $\begin{array}{l}\text { Local and internationally funded construction projects } \\
\text { above E5 million but below E10million. }\end{array}$ \\
Category B & 13 & 0 & $\begin{array}{l}\text { Local and internationally funded construction projects } \\
\text { above E1million but below E5million. }\end{array}$ \\
Category C & 20 & 0 & $\begin{array}{l}\text { Local and internationally funded construction projects } \\
\text { above E500, 000.00 but below E3million. } \\
\text { Category D }\end{array}$ \\
\hline
\end{tabular}

Source: Ministry of public works and buildings department: 2007.

\subsubsection{Problems Facing Small and Medium Size Contractors in Swaziland}

The problems facing small contractors are not unique to Swaziland. The vast majority of construction firms are small enterprises that rely on outsourcing personnel as required. This has severely affected skills training and the retention of expertise in the industry as construction workers become highly mobile, walking in and out of the industry, depending on performance in other sectors of the economy. The impact can be seen in the rigid adherence to management techniques and construction practices handed down from colonial times which, as a result of inadequate skills and capacity.

\subsection{Research Methodology}

The paper used both primary and secondary data. Literature review on small contractors was conducted. A questionnaire was designed with the help of the statistical Consultation Service (STATKON) of the University of Johannesburg. A field survey was carried out on 15 companies; the study target population includes 100 contractors currently registered with the Ministry of Public Works and Transport Roads and Building sections. The Ministry of Public Works and Transport the Ministry of Public Works and Transport serves as a regulatory body for the construction industry in Swaziland. Swaziland is divided into four administrative regions; that are Hhohho, Manzini, Lubombo and Shiselweni. Data was collected between the $1^{\text {st }}$ of June 2007 and $30^{\text {th }}$ July 2007 and 87 respondents were interviewed. A total of one hundred (100) questionnaires were distributed to various contractors registered under categories D, C, B (small) and A and M1 (medium) with the Ministry of Public Works and Transport Buildings Department contractor register and contractors registered under categories 6, 5, 4 (small) and
3 and 2 (medium) with the Ministry of Public Works and Transport Roads Department contractor register. Contractors registered under these categories are regarded as small and medium contractors, respectively. The questionnaire was distributed to senior personnel including directors, project and construction managers. Out of the one hundred (100) questionnaires distributed, eightyseven (87) were returned. Thirteen (13) questionnaires were not returned by the respondents. (See Figure 1)

The Kingdom of Swaziland is a landlocked country surrounded by the Peoples' Republic of Mozambique in the east and the Republic of South Africa's Kwa ZuluNatal Province in the south and the Republic of South Africa's Mpumalanga Province in the west and in the north. The Kingdom of Swaziland has a population of around 1,128,814 inhabitants on 17,363 sq km of land.

\section{Findings of Research 2009}

The problems facing small contractors are not unique to Swaziland. The vast majority of construction firms are small enterprises that rely on outsourcing personnel as required. This has severely affected skills training and the retention of expertise in the industry as construction workers become highly mobile, walking in and out of the industry, depending on performance in other sectors of the economy. The impact can be seen in the rigid adherence to management techniques and construction practices handed down from colonial times which, as a result of inadequate skills and capacity. Delays with interim and final payments, as well as onerous contract conditions faced by construction firms, can also impose huge constraints on the industry. Many construction firms have suffered financial ruin and bankruptcy because of delays in payment, which are common with government contracts. Contemporary research that was conducted in 


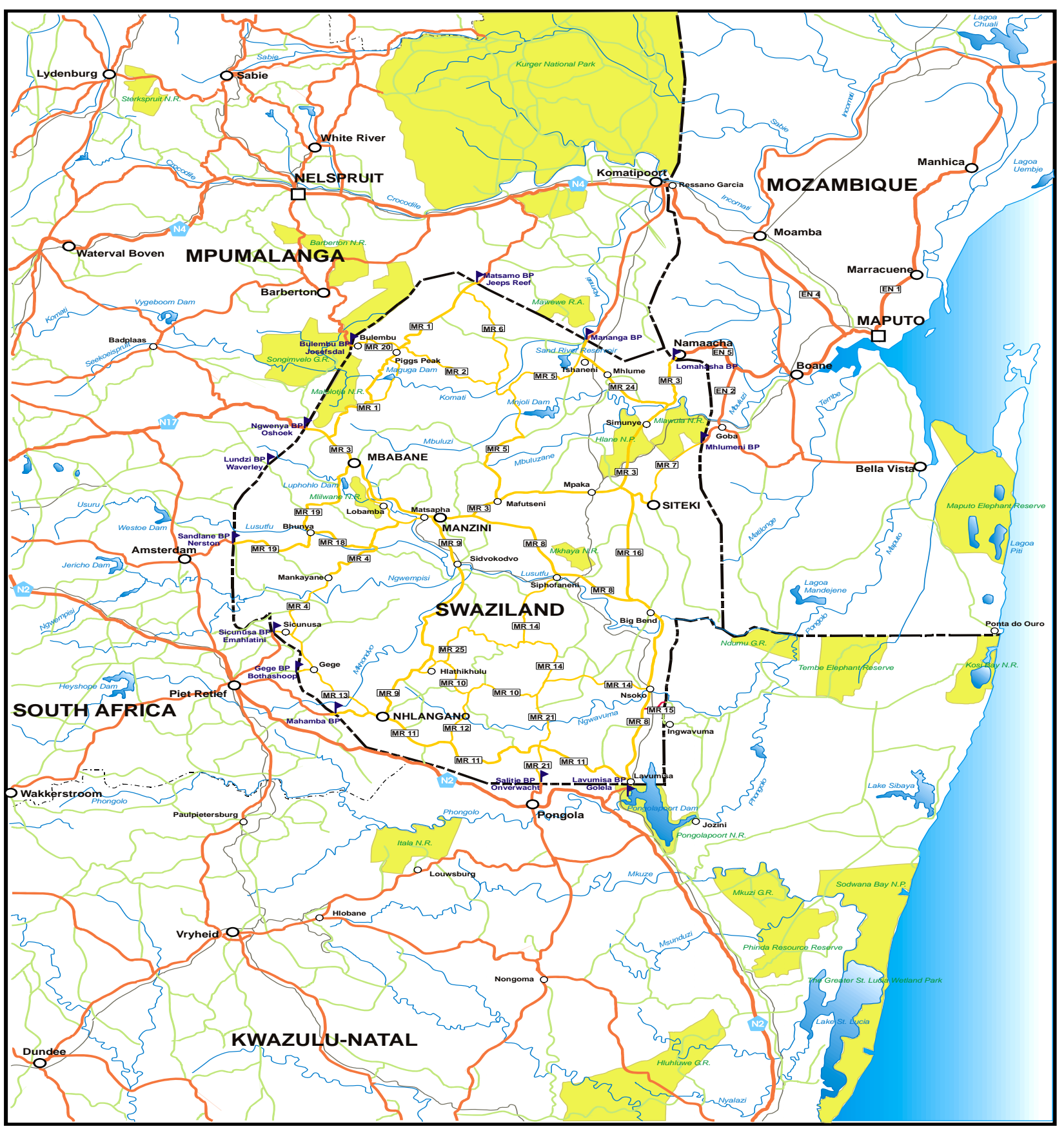

Figure 1. General survey offices, ministry of natural resources, Swaziland, 2009

2007 by the authors revealed the current reasons for the failure of small and medium size contractors in Swaziland. 87 owners of the small and medium size contractors were interviewed. $68 \%$ of the contractors are less than four years; 20\% are between 5 and 9 years; and $12 \%$ had operated for more than 10 years. There was no contractor that had operated more than 15 years. $63 \%$ of the respondents believe that the four major banks in Swaziland have proper systems in place to support small and me- dium size contractors once they have secured work. On the other hand $37 \%$ of the respondents do not believe that the four major banks in Swaziland have proper systems in place to support small and medium size contractors. $33.4 \%$ of the respondents think that the current environment within the construction industry in Swaziland is favorable for small and medium size contractors to be successful. On the other hand $66.6 \%$ of the respondents believe that the construction industry environment is not 


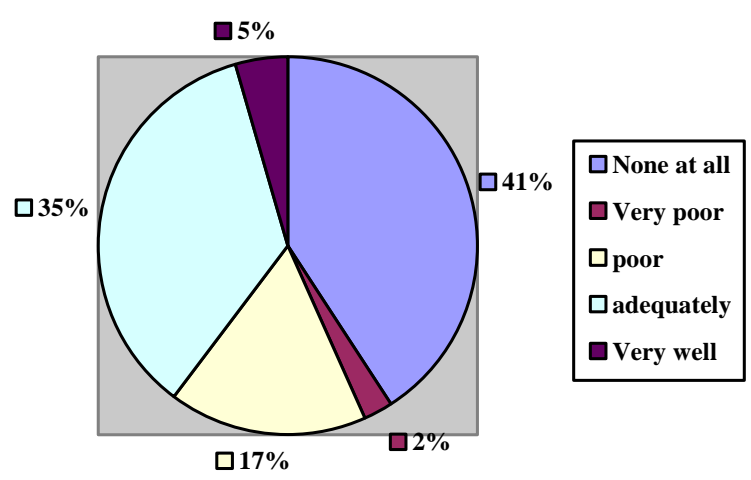

Figure 2. Develop business skills

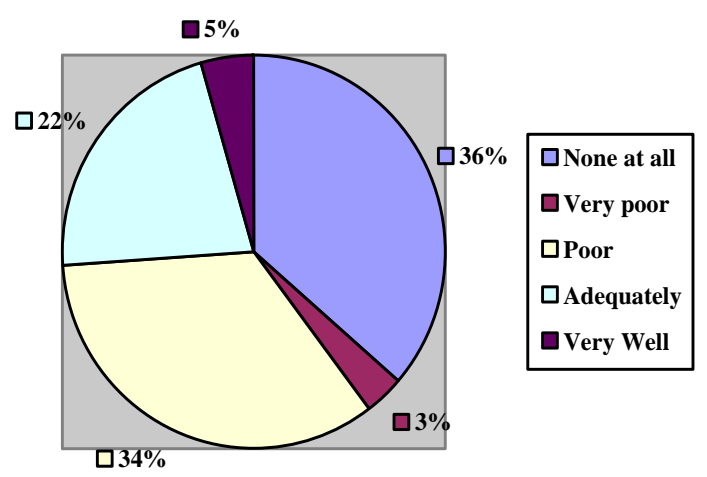

Figure 3. Develop management skills favorable for the success of the small and medium size contractors.

From the above figure $40 \%$ of the respondents are satisfied with business skill development and $60 \%$ of the respondents were not satisfied. The figure above shows that the respondents are not satisfied with regard to the development of business skills. (See Figure 2)

From the above figure $27 \%$ of the respondents are satisfied with the development of managerial skills. 73\% of the respondents are not satisfied with the development of managerial skills. It is clear from the above figure that respondents had not been trained. (See Figure 3)

From the figure below $47 \%$ of the respondents are satisfied with the development of technical skills. 53\% of the respondents are not satisfied with the development of technical skills. (See Figure 4)

From the research conducted it can be concluded that the relative lack of success among the small and medium size contractors in Swaziland is a results of the following problems which must be addressed in order for the contractors to be successful:

- A lack of resources for either large or complex construction work.

- An inability to provide securities, raise insurance and obtain professional indemnity.

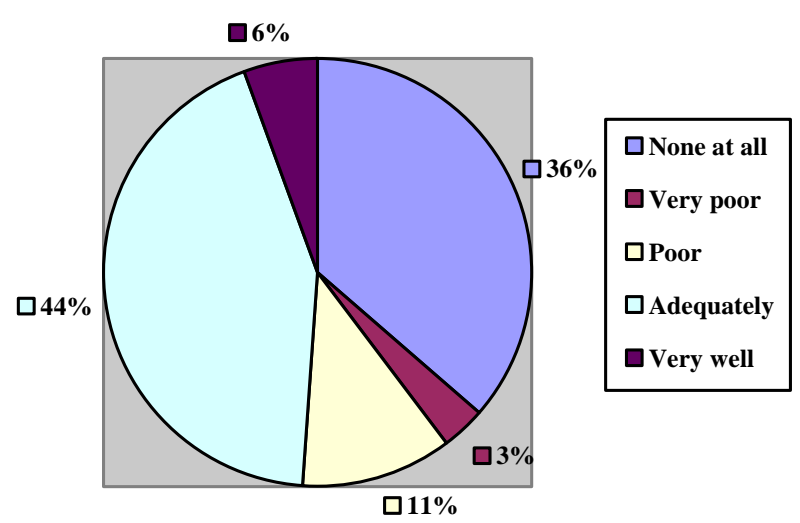

Figure 4. Develop technical skills
- $\quad$ The contracts were inevitably packaged in such a way as to exclude small contractors.

- Inadequacy in technical and managerial skills required in project implementation.

- $\quad$ Lack of continuity in relation to type, scale and location of work

- An inadequate approach and insufficient knowledge, time and experience required for the whole process of finding work, once found, insufficient understanding of the contract documentation and the preparation and submission of tenders.

- $\quad$ Slow and non-payment by government after completing a government project

- $\quad$ Little or inadequate effort has been made to identify the causes of failure among the local contractors in the implementation of construction projects in Swaziland.

- $\quad$ The need for the introduction of a set of rules to govern the construction industry done by an independent body in the Kingdom of Swaziland.

\section{Lessons and Recommendations}

The literatures that have been reviewed both in Swaziland and internationally demonstrated that the development of Swazi contractors, small and medium sized contractors faced several challenges which must be addressed. In the case of Swaziland the majority of the respondents are dissatisfied with the quality of assistance offered by the government to the small and medium sized contractors in Swaziland. Small enterprises contribute positively to the economics of the country and to the survival of large numbers of people. However, the success of small enterprise is impaired by the common weakness from which many enterprises suffer. A vibrant self-sustaining construction industry is one that is planned and matched with government capital programmes and support schemes aimed at improving the efficiency of the local construction industry. Swaziland is faced with a large challenge of developing infrastructure in the disadvantaged communities, and also upgrading the existing 
infrastructure to cope with the high demand. It is recommended that the Swaziland Government must undertake the following measures to address the challenges facing Small and Medium Size contractors:

- $\quad$ Business skills: training in business management skills is key the in managing a construction business effectively and efficiently.

- Management skills: financial management should be emphasized as well as networking with other people with similar businesses

- $\quad$ Good record keeping: financial records should be prioritized and a record of books of accounts on a daily, weekly, monthly and annual basis should be established.

Well managed cash flow: prepare cash flow forecasts and budgets and prepare a cost-benefit analysis.

- The government should break down big contracts into small contracts so that small contractors with lower grading can qualify to do the job

- $\quad$ The government should assist in training Small and Medium Size contractors on business management

- The government should create a construction advice centre

- $\quad$ The government should establish a Contractor Training Institute to train Small and Medium Size contractors

- $\quad$ Government payment system must be improved

- $\quad$ Government must establish financial institutions that will act as guarantees in order to enable contractors to have access to finance.

\section{Conclusions}

The literatures that have been reviewed both in Swaziland and internationally demonstrated that the development of Swazi owned contractors, small and medium sized contractors, in particular are face many challenges which need to be addressed in order for the contractors to sustainable in their growth. The majority of the respondents are dissatisfied with the quality of assistance offered by the government to the small and medium sized contractors in Swaziland. The problem lies, however, in the formation of a construction industry in line with the implementation of government programmes that must facilitate the creation of a vibrant self-sustaining construction industry. A vibrant self-sustaining construction industry is one that is planned and matched with government capital programmes and support schemes aimed at improving the efficiency of the local construction industry. The study finds that lack of effective management during their early stages is a major cause of business failure for small and medium sized contractors. Owners tend to manage their businesses themselves as a measure of reducing operational costs. Poor record keeping is also a cause for start-up business failure. Lack of financial management; lack of entrepreneurial skills; lack of proper training; lack of resources; lack of technical skills, lack of contractual and managerial skills; late payment for work done which are common with government contracts; inability to get credit from suppliers and fronting for established contractors are also contributing factors for the failure of small contractors in Swaziland.

\section{Acknowledgements}

Research works in this paper are partial supported by the National Research Foundation (NRF) and the University of Johannesburg Research Funding.

\section{REFERENCES}

[1] Ministry of Public Works and Roads, "Swaziland. Swaziland today,” 2007, http://www.gov.sz.

[2] Construction Industry Development Board, "South Africa construction industry status report - Synthesis review on the South African construction industry and its development. Discussion document,” South Africa, 2004.

[3] National Advisory Council on Innovation, “The potential impact of skills shortages on the innovative capacity of major capital engineering projects," National Advisory Council on Innovation and Department of Science and Technology, Pretoria, 2003.

[4] Construction Industry Development Board, Department of Public Works, Construction Education and Training Authority, "Towards a common framework for enterprise growth and sustainability," Sustainable contractor development, National Workshop, Pretoria, 2005.

[5] A. Kesper, "Failing or not aiming to grow? Manufacturing SMMEs and their contribution to employment growth in South Africa,” TIPS Working Paper 15, 2000.

[6] D. Matas, "Towards the new millennium series: No more: The battle against human rights,” Ottawa, Dundurn Press, 1996.

[7] Statistics South Africa, "Labour force survey for september 2005,” Statistics South Africa, Pretoria, 2005.

[8] M. K. Nissanke, "Financing enterprise development in sub-Saharan Africa," Cambridge Journal of Economics, Vol. 25, pp. 343-367, 2001.

[9] C. M. Rogerson, "Unpacking tourism SMMEs in South Africa: Structure, support needs and policy response," Development Southern Africa, Vol. 22, pp. 623-642, 2005. 